Srđan Jončić

Original scientific paper

UDC: 342

doi: $10.5937 /$ spzo-20371

\title{
CONFLICT OF THE AUTHORITY OF JUDICIAL POWER AND NON-JUDICIAL INSTITUTIONS
}

\begin{abstract}
The subject of the analysis of this paper is the mutual relation between the judicial authorities and non-judicial institutions, those whose decisions directly or indirectly influence the exercise of judicial power'. The author's attention will not be directed towards relations with institutions of legislative and executive power, but on non-judicial institutions that do not belong to governmental ones, and have an impact on judicial decision making. This relationship will be presented through the prism of the conflict of authority, which is based on the institutional position of the analyzed institutions, the legal effect and the possibility of reconsidering their decisions, and the conflicting relationship in the decision making process. The complexity of the analyzed relationship also speaks of the dilemma of the author regarding the name of this paper, so the analysis can thus be described as "the interrelation of the judicial authorities and non-judicial institutions, as an attachment to the functionality or dysfunctionality of the legal system", "encroaching on powers of judicial authorities by non-judicial institutions", "allowed and disallowed operation frameworks for non-judicial institutions in relation to the exercise of judicial power", or "conflict of jurisdiction between regular courts and non-judicial institutions". It seems that, regardless of the different angle of observation, and the different marking of the disputed points, the essence of the disputed relationship is precisely the authority of the analyzed institutions, the conflict based on legitimate reconsidering of judicial decisions (a real conflict of authority), and a potential conflict in case of an illegitimate impact (not real conflict of authority).

Non-judicial institutions whose relationship with the judicial ones is being considered are the Constitutional Court and the State Audit Institution,

\footnotetext{
* Judge of the First Basic Court in Belgrade, e-mail: asjoncic@gmail.com.

${ }^{1}$ Hereinafter, depending on the context, the terms "judicial authority", "ordinary courts", "Supreme Court of Cassation", will be used.
} 
which, regardless of whether it is an allowed or disallowed influence, have the possibility, due to the nature of their position and the nature of the decisions, influence the exercise of judicial power.

Keywords: Constitutional Court, judicial power, State Audit Institution, conflict, basic rights, authority of institutions.

\section{The authority of the institutions}

Common to the Supreme Court of Cassation as an exponent of the exercise of judicial power on the one hand and the Constitutional Court and the State Audit Institution on the other, is their "institutional authority", as well as "the authority of decisions i.e. acts made". As constitutional categories, they base their institutional authority on the Constitution as the highest legal act. According to the letter of the Constitution, the Supreme Court of Cassation is ,the highest court in the Republic of Serbia"2, the Constitutional Court is "an autonomous and independent state body that protects constitutionality and legality and human and minority rights and freedoms", while the State Audit Institution is "the highest state body for the audit of public funds in the Republic of Serbia, is autonomous and subject to the control of the National Assembly, to which it is accountable"4.

On the other hand, the authority of the decisions taken, which is reflected in the legal effect of the decisions and the possibilities of their review, is not only established by the Constitution, but also by the relevant laws regulating the field of operation of these institutions. The Constitution defines that court decisions are "mandatory for all and cannot be subject to extra-judicial control" and "can only be reviewed by the competent court in the legally prescribed procedure", and that, on the other hand, "the decisions of the Constitutional Court are final, executive and mandatory"'. When talking about the State Audit Institution, the situation is somewhat different, in that the actions of the Institution are not determined as a decision, but as acts of the Institution and that the legal effect of decisions or acts, is defined by the Law ${ }^{7}$. Thus, the decision making authority received its expression in a provision that stipulates that

\footnotetext{
${ }^{2}$ Art. 143, par. 4 of the Constitution of the Republic of Serbia - Constitution of RS, Official Gazette, No.98/2006.

${ }^{3}$ Art. 166, par. 1 the Constitution of the Republic of Serbia.

${ }^{4}$ Art. 96, par. 1 the Constitution of the Republic of Serbia.

${ }^{5}$ Art. 145, par. 3 and par. 4 the Constitution of the Republic of Serbia.

${ }^{6}$ Art. 166, par. 2 the Constitution of the Republic of Serbia.

${ }^{7}$ The Law on State Audit Institution - Law on SAI, Official Gazettes of the Republic of Serbia, No. 101/2005, 54/2007 and 36/2010.
} 
"the acts by which the Institution exercises its audit authority cannot be challenged before the courts and other state bodies"8.

The lack of a constitution and law established subordination between the analyzed institutions (it would not be possible), and insisting on "exclusive" positions and rights ${ }^{9}$, necessarily leads to a conflict of authority.

\section{The judicial power and the constitutional court- real conflict of authority}

Positioning the Constitutional Court to non-judicial institutions is not aimed at minimizing the role and importance of the Constitutional Court, but it is rather a result of a clear constitutional distinction with the judicial authority at the top of the pyramid of which is the Supreme Court of Cassation as the highest court in the Republic of Serbia, or the highest court in the system of regular courts. Also, the contribution to this demarcation give the constitutional definition of the Constitutional Court as an autonomous and independent "state organ", as well as a normative split in relation to judicial power.

The basis of the conflict of authority between the judicial power and the Constitutional Court lies with the Constitutional Court's authority to review judicial decisions when fundamental human rights and freedoms are violated ${ }^{10}$. Given the legitimacy of the Constitutional Court, we are talking about the real conflict of authority.

The critique of this "new" jurisdiction of the Constitutional Court is moving in three directions:

The first is based on the attitude of the inadmissibility of reviewing court decisions by institutions outside the judicial system, which is why such a model of the functioning of the Constitutional Court is characterized as contrary to the principle expressed in Article 145 paragraph 4 of the Constitution. This traditional attitude stems from the essence of relations with the Constitutional Court, which is why it is largely abandoned, and it seems that the dogma about the inviolability of judicial decisions ${ }^{11}$ is a past. However, although abandoned, its permanent presence cannot be denied, which strengthens with every defect in constitutional law

\footnotetext{
${ }^{8}$ Law on SAI, art. 3, par. 4.

${ }^{9}$ V. Petrov, On the change of constitution and Constitutional Court, interview, https:/www.paragraf.rs/intervju/vladan petrov.html, December 15, 2018.

${ }^{10}$ Hereinafter "fundamental rights".

${ }^{11}$ D. Stojanović, „Ustavnosudsko ispitivanje sudskih odluka”, Zbornik radova Pravnog fakulteta u Nišu 74/2016, 35-37.
} 
protection of fundamental rights, especially in the segment of protection subject, and non-existence of clear distinction between the category of specific constitutional law and ordinary law.

The second concept of criticism is based on challenging the way to eliminate the consequences of violations of fundamental rights in court decisions. Advocates of the said concept consider the annulment ${ }^{12}$ or cancellation ${ }^{13}$ of court decisions by the Constitutional Court a threat to the authority of the judicial power. As an alternative, the possibility is offered that by its decision the Constitutional Court only finds that a court decision violates some of the basic rights, and afterwards everything is returned to the appropriate court procedure. The decisions of the Constitutional Court would so have a "declaratory character", as with the decisions of the European Court of Human Rights ${ }^{14}$. In this way, the legal effects of a decision of the Constitutional Court could be achieved through the filing of an appropriate extraordinary legal remedy, and in that context, through the application of the provisions relating to the institute of renewal of proceedings ${ }^{15}$.

The third direction of criticism relates to the established aspiration of the Constitutional Court, that in invoking the protection of fundamental rights in its decisions, it often enters into substantive and procedural issues within the jurisdiction of the judicial power. The taking of legal opinions by the Constitutional Court concerning legal issues within the jurisdiction of courts of record would be a threat to the established system of protection of fundamental rights, in which way the dysfunctionality of the whole of the legal system would be significantly contributed.

\section{Basic rights as ,specific constitutional right”}

The task of the Constitutional Court is not to take the stand whether a court decision is good or not good "for parties" rather than provide the answer to the question whether it is good or not good "for society". To this determinant can also be added the following conclusions:

\footnotetext{
${ }^{12}$ Practice of the Constitutional Court of the Republic of Serbia.

${ }^{13}$ Practice of the Federal Constitutional Court of Germany, one of BVerfGE 128, 226.

${ }^{14}$ M. Nastić, „Odnos Ustavnog suda i redovnih sudova - komentar odluke Ustavnog suda Republike Srbije", Zbornik radova Pravnog fakulteta u Nišu 65/2013, 379.

${ }_{15}$ N. Bodiroga, „Ponavljanje parničnog postupka zbog odluke Ustavnog suda”, Anali Pravnog fakulteta u Beogradu 2/2013.
} 
- that the judicial authority gives an answer to the question of what is right, and the Constitutional Court - what right should be (M. Arlović) ${ }^{16}$,

- that a specific constitutional right will not be hurt when a regular court passes some, given the usual right, objectively wrong decision, but it must be violation of one of the fundamental (basic) rights guaranteed by the Constitution, i.e. specific constitutional law. (S. Rodin) ${ }^{17}$

By analyzing these conclusions we can come closer to understanding the notion of a specific constitutional law $w^{18}$. The specificity of constitutional law has two aspects:

- the first one that relates to a specific subject of protection. Thus, the focus of constitutional protection is directed only and solely on the protection of fundamental rights, and

- the second aspect observed in the broader sense is the specific jurisdiction of the Constitutional Court in the protection of fundamental rights that are violated by court decisions. This specificity is reflected in the extraordinary authority of the Constitutional Court to review court decisions merely and only in the domain of respect for fundamental rights.

By positioning the Constitutional Court as a protector of fundamental rights, it automatically dissociates this institution from encroaching into "ordinary rights" that are the subject of a dispute before the courts. Thus, the Constitutional Court would exclude the discussion of rights from property relations, family relationships, labor relations and the like. In this way, the judicial authority retains the "exclusive right" to decide on the rights of the parties, and retains the position of the decision maker in the domain of "ordinary law". These decisions, if they are made in accordance with fundamental rights, cannot be subject to review outside the judicial system of authority. On the other hand, it is made possible for the Constitutional Court to intervene in the framework of protection of fundamental rights, which, as a sort of "overright" stands above the

\footnotetext{
${ }^{16}$ M. Arlović, „Međuodnos Ustavnog suda Republike Hrvatske i sudbene vlasti u Republici Hrvatskoj”, Zbornik radova Pravnog fakulteta u Splitu 2/2015, 387: "While the judiciary, in principle, responds primarily to the question of what is the right in a country of the rule of law and legal security, a constitutional court must answer the question what right should be".

${ }^{17}$ S. Rodin, „Odnos Ustavnog suda Republike Hrvatske i Suda pravde Europskih zajednica u Luksemburgu nakon ulaska Republike Hrvatske u punopravno članstvo Europske unije", https://www.google. com/url? sa $=t \& r c t=j \& q=\& e s r c=s \&$ source $=w e b \& c d=5 \& v e d=2 a h U K E w j R O r X O 65 \mathrm{LgAhXos} 4 \mathrm{sKHcOiC}-$ 7cQFjAEegQIBRAC\&url=https\%3A\%2F\%2Fbib.irb.hr\%2Fdatoteka\%2F388258.tekst_Rodin_out_final. doc\&usg=AOvVaw27rTpKT_4do5YVfV3Gdtdf, 7.

${ }^{18}$ Among others, S. Rodin, section 1.3.a. "Distinction of a specific constitutional right from ordinary law"; D. Stojanović, part 3.1. "Violation of specific constitutional law”; J. Omejec, ,Jurisprudencija nemačkog Saveznog ustavnog suda i hrvatsko ustavno sudstvo", u: Izbor odluka Ustavnog suda Savezne republike Nemačke (ur. Tobias Zern, Martin Bauch), Zaklada Konrad Adenauer program, Zagreb 2015, 21-23.
} 
private interests of the participants in the court proceedings, and includes an increased public interest in its protection (specific constitutional law).

In such "division" of jurisdiction, the consideration of the position of the Constitutional Court as a "super-revising court" and disrespect of a specific position and jurisdiction, which this court has today, are excluded. Our society, by entrusting the Constitutional Court with jurisdiction over the review of court decisions in the domain of protection of fundamental rights, has placed our country among the European countries with the same protection principle (the European model) ${ }^{19}$.

\section{Limits of reconsidering judicial decisions}

Defining the basic rights as an object of protection, in the decisions of the Constitutional Court to review the court decisions, is not in itself sufficient. Based on this general definition, the constitutional court practice had to answer the question, what are the situations when a court decision violates some of the basic rights. In practice, the Constitutional Court of the Federal Republic of Germany has crystallized several characteristic situations ${ }^{20}$ of violation of fundamental rights by the court:

- when the court of record violates any of the constitutionally guaranteed fundamental procedural rights of the parties to the proceedings

- when the court of record applies a law that is contrary to the constitutionally guaranteed fundamental rights

- when the ordinary court of record interprets the law or enforces the law in a manner contrary to fundamental rights;

- when the court of record passes a decision arbitrarily (arbitrariness).

\subsection{Application of the law and taking of a position that is contrary to the basic rights}

When it comes to situations that involve the application of laws and the taking of views that are contrary to fundamental rights, it seems that the matter is quite clear. In both cases, the application of any provision of the law was excluded, the application of which would lead to the violation of a guaranteed basic right. This implies the first situation where the application of provisions that are contrary to fundamental rights is forbidden. In this case, the ${ }^{19}$ O. Vučić, D. Stojanović, „Evropski model ustavnog pravosuđa”, Zbornik radova Pravnog fakulteta u Nišu 69/2015.

20 S. Rodin, 6. referring to Benda/Klein, Lehrbuch des Verfassungsprozebrechts, C.F. Müller Juristischer Verlag, Heidelberg 1991, 253, note 43 and BVerfGE 11, 343 (349) and especially BVerfGE 18, 85. 
Constitutional Court is authorized to annul a court decision based on a provision of a law that is contrary to the constitutionally guaranteed basic rights in the proceedings under a constitutional complaint, even in a situation where those provisions were not subject to constitutional review. ("direct control of the constitutionality of the law")

In another situation, the prohibition refers to the acceptance of attitudes in the application of the law, which would be contrary to the guaranteed fundamental rights and freedoms. A characteristic case that can be classified in the wider sense in this model of injuries and which at the moment represents the "painful point" of our legal system is to take over the position of the court, which is opposite to either horizontally or vertically harmonized court practice.

\subsection{Violation of the basic procedural rights of the parties}

The situation in which a court violates one of the basic procedural rights of the parties is the only one mentioned, which refers to the existence of a formal defect. The complexity of the problem in this type of violation is reflected in the obligation of the Constitutional Court to take a stand on which procedural rights would have the character of the basic ones, and which are ordinary. The answer to this question is crucial for assessing whether the violation of the procedural law of the parties enjoys constitutional protection or not. Unlike the previous two situations mentioned above, where the violation is of material nature and therefore "more visible", in the case of procedural defect, the thing is different. It is simply impossible to "line up" the line and make a clear distinction between ordinary injuries and basic procedural injuries.

The division of the breach of proceedings into absolutely essential and relatively significant violations in procedural laws could not be helpful. Namely, absolutely essential procedural violations should not be classified in the category of violation of basic procedural rights by automatism. If the solution of the problem was set up in this way, a paradoxical situation would arise that the Constitutional Court, in relation to the absolutely essential violations of the procedure, proceeds in the same way as a second instance appeals court, that is, as a court of review. Bearing in mind the aforementioned premises, it is clear that there is no possibility of "codifying" procedural injuries, which would have the character of the basic ones, and that is why the help in taking over the position could come from the other side.

\footnotetext{
${ }^{21} \mathrm{Ibid}, 10$. note by the author "concrete control of the constitutionality of the law".
} 
All absolutely essential procedural violations (or at least the majority) can be broadly subsumed under a violation of the right to a fair trial. When analyzing two groups of possible situations, there would be obvious differences in the nature of the injury.

The first group of assumed situations would be:

- in the course of many years of civil procedure, in one of its stages one of the submissions has not been submitted to the opposite party. This would be a violation of the hearing principle, which is defined as an absolutely essential injury;22

- during the procedure, a person who is not familiar with the language in official use in the court is prevented from engagement of a court interpreter at one or more hearings, on which no evidence has been produced, nor has it been pointed out that there is a fact essential to the resolution of the dispute. In this case, it would be possible to talk about a violation of the right to equal protection before a court that would also qualify as an absolutely essential violation ${ }^{23}$.

In a wider sense, both cases could be qualified as violations of fundamental rights, violations of the right to a fair trial. The degree of vulnerability of fundamental rights is different between these two examples of the same group, in favor of the other, where the degree of vulnerability seems to be greater than in the first situation. However, given the low degree of intensity of injury in both cases, the question arises as to whether the mentioned procedural deficiencies should be classified as a violation of fundamental rights, and with the intervention of the Constitutional Court, the proceedings should be brought back to court, thus risking the establishment of conditions for establishing a violation of the right to trial in a reasonable time.

Unlike the mentioned group of cases where it is justifiable to ask the question of the purpose of annulment of a court decision, in some other situations this is set as a necessity. Then we could talk about the second group of assumed situations:

- during many years of civil proceedings, the submissions have not been submitted at all or in most cases to one of the litigious parties

- a person who does not know the language that is in official use in the court shall be prevented from engagement of a court interpreter during the entire procedure.

\footnotetext{
${ }^{22}$ Art. 374, par. 2, point. 7. of the Law on Civil Procedure - LCP, Official Gazettes of RS, Nos. 72/2011, 49/2013, 74/2013, and 55/2014.

${ }^{23}$ Art. 374, par. 2, point. 8. LCP.
} 
Unlike the previous group of cases, there is a significantly higher intensity and a significantly higher degree of vulnerability to violations of basic rights. Therefore, it could be said that situations from the second group of procedural violations infringe upon the very essence of the procedure and essentially jeopardize the position of the party.

The above examples lead to the conclusion that in taking an attitude about the character of a procedural violation, the broadest interpretation of the established standards of respect for human rights should not begin, because it would be counterproductive for the entire legal system. On the other hand, we should bear in mind the terms and qualifications that follow human rights and freedoms ${ }^{24}$, and which can certainly indicate the required high level of seriousness of the violations that would be sanctioned. Violations of procedural rights that cannot be said to compromise the foundations and basic values of a society, and which can be attributed only to the lack of a form, but not to the substance, must not be the subject of constitutional and judicial protection.

\subsection{Arbitrariness in decision making}

Arbitrariness in decision making, as one of the characteristic situations of violation of basic rights, enjoys certain specificities. This violation should be distinguished from seemingly similar situations, which due to their (un)importance do not enjoy protection as violations of basic rights.

Therefore, this situation should be distinguished from the following:

- when in its decision the court does not refers at all, or it wrongly refers to the provisions of the law on the basis of which the decision was made. In these cases, there are benign shortcomings, which are very easily corrected in the appeal or review procedure.

- If the court decides on a determined factual situation in accordance with the law, and if the explicit non-recourse or misapplication of the provisions of the law is the only defect, it would not be a reason for the cancellation of the decision.

- when in its decision the court refers to "free judicial conviction". The use of the right to a free judicial conviction is a legitimate and based on the law authority ${ }^{25}$, which is diametrical in relation to the position

\footnotetext{
${ }^{24}$ Basic, fundamental, guaranteed, overright, and the like.

${ }^{25}$ Among other articles 8 (free evaluation of evidence) and 232 (free assessment of the amount of material damage) of LCP.
} 
of illegitimacy of arbitrariness in decision making.

- when the court decision did not give reasons for decisive facts. This violation, defined as an absolutely essential injury ${ }^{26}$, also distances itself from the system of protection of fundamental rights.

In contrast to this, the arbitrariness in deciding exclusively falls within the domain of material defect or lack of essentiality. A characteristic situation of arbitrariness is the interpretation of the provision of the law in a way that is contrary to its clarity and precision. In other words, a legal norm that is clearly defined and which does not leave the possibility of a different interpretation of what it says is interpreted to the contrary. In this situation, there is a clear need to "eliminate" the arbitrary interpretation of the norm, but there is a clear danger that the Constitutional Court will take a different attitude from the attitude taken in the court decision, considering that its position fully reflects the essence of the analyzed provision of the law.

As with the violation of basic procedural rights, a question also arises how deeply one can analyze the court decision to avoid the risk of taking positions in the jurisdiction of the judicial authority.

\subsection{Three-dimensional quality of analysis and the rule "at first sight"}

The concept of the boundary of the review of a court decision can be seen from two aspects. The first one determines the jurisdiction, i.e. the framework of the Constitutional Court's functioning in the analysis of court decisions, and then we are talking about the analysis "in breadth", that is, about the two-dimensional character of the analysis. On the other hand, the analysis of court decisions by investing "in depth" of court proceedings in order to exercise jurisdiction over the protection of fundamental rights, could represent a three-dimensional character of the analysis.

Entering into the depth of the court proceedings constitutes a risk for the Constitutional Court - to create a need for taking a position on procedural and substantive matters and even to deal with the analysis of the established factual situation. In this way, the Constitutional Court, from the analysis of the violation of fundamental rights, would move to the level that implies the analysis of ordinary law, which is within the jurisdiction of the judicial authorities. One of the possible solutions based on which the problem would be overcome is the application of the "at first sight" rule.

${ }^{26} \mathrm{LCP}$, art. 374, par. 2, point 12. 
The character of the violation of basic, or fundamental rights, seems to imply a more pronounced degree of obviousness. In other words, this means that violation of fundamental rights in the review process of court decisions must be obvious, and already "at first sight" ascertained. The importance of the violation is, on the one hand, by some unwritten rule, proportionate to its obviousness on the other. By such an approach to resolving a disputed relationship with a constitutional complaint, the Constitutional Court could doubt the importance of the violation of fundamental rights if it was not obviously established, that is, in the first or second step. Also clearly evident and obvious violation of basic rights can strengthen the need for the activation of the protection mechanism at the Constitutional Court.

If the above two situations, which involve violation of basic procedural rights and arbitrariness in decision making, applied the rule "at first sight", then the definition of characteristic situations of violation of fundamental rights should include the notion of obviousness.

The rule "at first sight" through the notion of "obvious", which would be defined as a rule of any written or unwritten character, would have the purpose of providing support to the Constitutional Court, not to cross the field of protection of ordinary law that is not within its competence.

Except in the social sphere, this rule seems to have its manifestation also in nature, where the most intense natural phenomena are almost always clearly perceptible and visible to the naked eye. If, on the other hand, the explanation of this model were to be found in philosophical doctrine, then it could be said that what is absolute reveals itself with the "flash of selfobviousness" ("flash of evidence"), that is, in intuition and not analytical scientific method ${ }^{27}$.

\section{5. "Self-limitation" of the Constitutional Court in the decision making process}

The Constitutional Court is in a kind of comfort zone in reviewing court decisions for violation of fundamental rights. Firstly, it manifests itself through the absence of the right to an effective remedy against its decisions, and secondly through the protection mechanism implemented in a unilateral proceeding. In a constitutional appeal procedure, one of the parties that is a party to a legal relationship decided by a court of record, nor does it participate in the proceedings on a constitutional complaint, nor is it, in most cases, aware that the proceedings have been initiated. In this way, the application of

${ }^{27}$ Henri Bergson, French philosopher (1859-1941) the work Creative Evolution (1907). 
the hearing principle is absent, although the legal effects of a decision of the Constitutional Court that annuls the decision of a court of record relates also to a party who did not participate in the relevant proceeding.

It seems that the Constitutional Court must be aware that its decisions that have not been made in accordance with the "rules of the game" can significantly contribute to the lack of harmonization of the legal system. For these reasons, in the absence of other mechanisms, the Constitutional Court must introduce significant factors of "self-restraint" and "self-control" in decision making so as not to take over the jurisdiction of courts of record by its decisions.

Thus, self-restraint and self-control of the Constitutional Court in the review of court decisions could go in several directions:

The first, which would represent a clear awareness that the Constitutional Court gives the first, and also, the last word about the violation of basic rights in court decisions.

The second, it would be based on the principle of not taking a position on matters within the jurisdiction of the judicial authority. It includes the non-determination of the Constitutional Court in relation to court decisions in substantive matters, procedural issues, and especially not according to the established factual situation,

The third would insist on constant communication with the Supreme Court of Cassation. This communication as M. Arlović states in the analysis of relations between the Constitutional Court of Croatia and the judiciary would rest on the principle of mutual cooperation and mutual checks ${ }^{28}$. If the position on the necessity of mutual cooperation is generally accepted, the entire future action would be based on the attitude of V. Petrov, that the protection of the constitutionally guaranteed rights as constitutional values is possible only with the complementary activity of both bodies ${ }^{29}$.

The last fourth direction would include the introduction of measures and criteria for assessing violations of fundamental rights. Thus, a "measure of obviousness" (the rule at first sight), a "measure of the intensity of the injury" $"$, and a measure based on the "degree of vulnerability" of social values, could be established as benchmarks.

By establishing control mechanisms in the process, a clear idea of the nature and seriousness of the violation of fundamental rights ${ }^{28}$ M. Arlović, 369.

${ }^{29}$ V. Petrov, see fn. 10.

${ }^{30}$ J. Omejec, 22 (referring to Rüth Christina and Lohse Kai) points to the practice of the German Federal Constitutional Court, which recognizes "the intensity of interference in fundamental law" as one of the measures of specific constitutional law. 
would be formulated, and the negative aspects of the functioning of the Constitutional Court would be mitigated or completely eliminated.

\section{Absence of control mechanisms and negative aspects of Constitutional Court actions}

The negative functioning of the Constitutional Court means the departure from the framework of a specific constitutional right and the transition to the field of common law, the understanding of the system of protecting the fundamental values of the society as a matter of form, not just the substance, and a very broad interpretation of the applied standards of protection of fundamental rights.

The absence of (self-)control mechanisms in the work of the Constitutional Court can lead to numerous negative consequences, among which are distinguished:

- threatening the authority of courts of record, and therefore the Supreme Court of Cassation as the highest court,

- devaluation the "victim status". This colloquial term refers to a person who has been violated with basic rights and who is seeking help and protection within the legal system. However, the status of the victim is "only enjoyed" by the person whose rights are essentially violated in the essential sense. Opposite him stands a person whose rights are hurt in the formal sense and it seems that he gets the status of a hunter, a person who "hunts" formal failures in court decisions. By presenting these omissions as a violation of fundamental rights, he wants to, through a positive decision of the Constitutional Court, bring the case back to the start and thus realize his private interests.

- devaluation of the human rights protection system which involves the transition from the level of "respect for fundamental rights", to the level of "respect for formal rights",

- threatening the authority of the Constitutional Court itself, which citizens increasingly view as an institution for the protection of their private interests (ordinary right), and less and less as an institution that represents a guarantor of respect for the Constitution, laws and fundamental values of a society (specific constitutional right)

- permanent danger of the so-called "DDOS effect" 1 . This term, taken from the information technology dictionary, implies the complete or

${ }^{31}$ DDoS is the abbreviation for the Distributed Denial-of-Service attack, and denotes the prevention of attacks on the computer system by utilizing many of the dispersed resources most found on the Internet. 
limited impossibility of functioning of the system, due to its overload. The Constitutional Court, by its actions, gives hope to the citizens to change the decision of the court of record before this court, not only from the domain of a specific constitutional right, but also from the domain of ordinary law (private-legal interest). For this reason, citizens are motivated to seek protection of their rights and before the Constitutional Court, whose effective treatment, due to a large number of requests, is almost completely disabled.

\section{A practical view of the conflict of the authority with the constitutional court}

\subsection{The obsolescence of the right to compensation for damage caused by criminal offense}

At a regular session held on July 7, 2011, the Constitutional Court delivered the position which refers to "the limitation period for damages caused by criminal offense", which (in part) reads as follows:

In the event that the damage is caused by a criminal offense (Article 377, LOO, Law on Obligations), if the period of obsolescence foreseen for criminal offense prosecution is longer than the deadlines prescribed in Article 376 of the Law on Obligations, the claim for compensation of damages to every responsible person, and not only the person who caused the damage, becomes obsolete when the time limit for statute of limitations expires only if the verdict has established the existence of a criminal offense and the defendant is found guilty of a criminal offense.

The Supreme Court of Cassation at the Civic Department session on March 10, 2015 took the following position:

Whenever the damage is caused by a criminal offense, if the period of obsolescence foreseen for criminal offense prosecution is longer than the deadlines prescribed in Article 376 of the Law on Obligations, the claim for compensation for damage to each responsible person, and not only the person who caused the damage, is outdated when the time limit for prosecution obsolescence expires only if the existence of a criminal offense is found by a final judgment and the accused found guilty of a criminal offense." (Sentence from the judgment of the Supreme Court of Cassation Rev1 41/2014 of December 12, 2014) 


\subsection{Interest on the costs of civil procedure}

The Appellate Court in Belgrade held a session of its Civil Division on December 24, 2014 and took the following position:

The obligation to compensate for litigation expenses is a monetary obligation that is due to the decision, to which the debtor is obliged to pay default interest from the decision making to the payment.

At the session of its Chamber held on November 19, 2015, the Constitutional Court decided to approve the constitutional complaint and annul the decision of the Commercial Court of Appeal, with a part of the explanation as follows:

The Constitutional Court considers that the debtor (litigation party) falls due only when the decision on the procedure expenses becomes final (either after the expiration of the appeal deadline, if the party did not appeal, or by passing a final decision on the appeal) and when the deadline for its voluntary fulfilment expires. Therefore, the arrival of debtor in arrears in this situation coincides with the moment when the decision of the court, by which he is obliged to compensate the litigation costs, becomes executive. Naturally, this consequently gives the right to the creditor from the executive document to claim from the debtor a default interest in accordance with the provisions of Article 277 paragraph 1 of the LOO.

(extract from Constitutional Court decision's (Už-9130/2013) citation)

By simple analysis of these examples it can be concluded that it is impossible to give a logical explanation that would justify the adoption of legal attitudes in the same legal matters by two institutions which act in different jurisdictional frameworks recognized by the Constitution and law.

\section{Judicial power and state audit institution - not real conflict of authority}

In relation to the judicial authority, the position of the State Audit Institution is diametrical to the Constitutional Court. This opposite position is reflected in an illegitimate impact on the judicial authority (not real conflict of authority), unlike the previously explained legitimate action of the Constitutional Court (real conflict of authority). The institution does not have the power to review or control the court decisions, but nevertheless, through its actions, there is a tendency to influence the judicial authority by taking positions on substantive issues. Given the competence of the Institution in the field of public funds audit, 
it is natural that the target groups of audit control are the beneficiaries of public funds (budget users). Among these beneficiaries, a certain number are legal entities in which citizens exercise their rights in the legally prescribed administrative procedure.

In its audit reports on these beneficiaries, the Institution often makes recommendations for the "proper application" of the law in the domain of that legal entity. As a rule, against the final administrative act of a legal entity, an administrative dispute can be brought before the competent Administrative Court, where that court would give a final opinion on the legality of the disputed administrative act.

It is precisely because of the fact that in the practice of the Institution it is noted that it makes recommendations and interpretations of legal solutions, and that these attitudes not only influence the scope of work of a controlled legal entity, but also the exercise of judicial power in the procedure of controlling the legality of the administrative act, we can also speak on the "indirect impact" on the judicial authority.

\section{Practical look at the conflict of the authority with the state audit institution}

One of the budget users whose work is subject to auditing is the Republican Pension and Disability Insurance Fund. For the sake of reminding, before the Fund, citizens enjoy their rights in the legal procedure prescribed in the law, in which two instances are provided ${ }^{32}$, and an administrative dispute may be brought against the final decision of the Fund ${ }^{33}$. For these reasons, if the Institution takes an opinion on the legal issue within the domain of the Fund's competence in the audit control, it indirectly encroach upon the competence of the Administrative Court, which, in the "last instance" in case of initiating an administrative dispute, will give the final view on the application of the law.

The example to be mentioned just refers to such a situation.

\footnotetext{
32 Art. 92 and Art. 99 Law on Pension and Disability Insurance - Law on PDI, Official Gazette of RS, Nos. 34/2003, 64/2004, 84/2004, 85/2005, 101/2005, 63/2006, 5/2009, 107/2009, 101/2010, 93/2012, 62/2013, $108 / 2013,75 / 2014$, and 142/2014.

${ }^{33}$ Art. 103, Law on PDI.
} 


\subsection{Costs of a burial}

During October-December 2013, the State Audit Institution audited the operations of the Republican Pension and Disability Insurance Fund and provided an appropriate audit report in which certain recommendations were given. The recommendation we are interested in was:

that the funeral expenses compensation is paid in the amount of one and a half average pension in the Fund in the previous quarter, in the same amount for all categories of pensioners, not for each category separately as was the case before the reporting.

The reason for passing this recommendation lies in the "disagreement" of the auditing institution with the previous position of the Fund, according to which the basis for the payment of one and the half average pension was calculated according to the average pension of the respective group of insured persons (agricultural pensioners, civil pensioners, etc.) In this way, lower reimbursement for the cost of funeral was paid for agricultural pensioners, given that their average pensions were lower than the average pensions of other groups of pensioners.

After the auditing institution took such an attitude, the question of removing the stated consequences of payment of less compensation was raised, i.e. whether the reduced payment would be eliminated by applying Article 105 of the Law on Pension and Disability Insurance, which means within the limits of the administrative procedure or administrative dispute, or in court proceedings by applying the institute of compensation for damages.

The answer to that question was given by the Supreme Court of Cassation through the position adopted at its Civil Division's session held on March 17, 2016 and it reads as follows:

A court of general competence is indeed competent to rule on a lawsuit in order to compensate for the unlawful or improper work of the administrative authority in connection with the payment of the difference from the amount paid to the pertaining amount of funeral expenses incurred as a result of the death of the beneficiary of agricultural pensions.

However, for the analysis of the topic of authority conflict, a more interesting is the part of the citation of the above paragraph that reads:

In this case, the jurisdiction of the administrative body prescribed by the Law on Pension and Disability Insurance for determining the right to payment of funeral expenses does not exclude the jurisdiction of a court of general competence to act in a lawsuit for compensation of damages 
due to illegal or irregular work of administrative bodies (article 1 of the Law on Civil Procedure and article 172, paragraph 1 of the Law on Obligations). When it comes to compensation for the funeral expenses of deceased users of agricultural pensions, paid in lower amounts than those pertaining to them, the State Audit Institution pointed out irregularities in the work of the Pension and Disability Insurance Fund.

(Extract of the part of the explanation of the position adopted at the session of the Civil Division of the Supreme Court of Cassation, held on March 17, 2016.)

The following conclusions can be drawn from this part of the reasoning:

- The Supreme Court of Cassation accepts the competence of the audit institution in taking over the position and interpretation of the provisions of the Law on Pension and Disability Insurance

- The Court also accepts and "verifies" the attitude of the audit institution in the meaning and application of the term "average pension" from Article 75 of the Law on Pension and Disability Insurance,

- The Court also accepts that the Fund has acted illegally and irregularly in terms of the attitude taken by the audit institution,

- The Court excludes the possibility of suspicion of the correctness of the position of an audit institution, in which way it establishes its binding application.

In this way, the Administrative Court did not fully exercise its competence in assessing the legality of the Fund's decisions in the administrative dispute (it was not initiated), nor was it possible for the court in the civil procedure to take an attitude (perhaps different) about (non) existence of illegality or irregularity in the Fund's work as the basis for compensation for damages.

Regardless of the fact that the stated attitude of the auditing institution is very likely correct, there were circumstances that could have been a basis for taking on a different attitude. The question of interpretation of the mentioned provision of Article 75 of the Law was raised in relation to the provision of Article 5 paragraph 1, which reads as follows: "rights from pension and disability insurance are acquired and realized depending on the length of investment and the amount of the base on which the contribution for pension and disability insurance has been paid, and with the application of the principle of solidarity".

In this situation, the question could arise whether the mentioned provision of the Law was met, that is, whether all groups of insured persons are entitled to the same amount of compensation, regardless 
of their various participations in investments, and a smaller amount of contributions for PDI paid, as is the case with agricultural pensioners.

The above example and the analysis did not aim to make a different opinion about the occupied attitude of the auditing institution, but to point to the fact that by taking over the position of the Institution, the courts of record have been circumvented, who are solely responsible for determining the unlawfulness of an administrative act (administrative court) or evaluation of illegal or irregular work as the basis for compensation for damages (competent court in civil procedure). If the problem arises within the jurisdiction of the Constitutional Court, which assesses the violation of fundamental rights, the question might be raised whether in the same factual situation there would be a place for acting on constitutional complaint and finding an arbitrary interpretation of the provision of Article 75 of the Law by the Fund, to the detriment of the party. In this situation, the condition would be the exhaustion of legal remedies as a condition of protection before the Constitutional Court, and in that sense the issue of the need for previous takeover of the position of the second instance administrative body, and finally the administrative court in the administrative dispute, would be raised, and only in that way it could be said that there are assumptions as a condition for submitting a constitutional complaint.

By taking a position and interpreting the provisions of the Law relating to the exercise of rights in the field of pension and disability insurance, which are in the domain of the jurisdiction of the Fund and the Administrative Court, a number of issues arise that mostly concern the issue of "conflict of authority in decision making".

\section{Instead of conclusion}

The Constitutional Court, the institutions of the judicial authority and the State Audit Institution are indisputably institutions with a high level of authority, both because of their position and the nature of their decisions. However, in this triple conflict, viewed from the practical aspect, only the authority of the judicial authority is questioned. If we admit it or not, the judicial authority is in a state of a kind of anxiety and depression, which is a direct consequence of:

- first, the inability to influence the review of its decisions by the Constitutional Court from the point of view of violation of fundamental rights,

- second, the impossibility of influencing the confrontation of the Constitutional Court with the views of courts of record in the domain of the 
application of common law and,

- third, the impossibility of influencing the encroachment upon court jurisdiction by institutions acting outside the system of constitutional control, as is the case with the State Audit Institution.

The stated restrictions on the judicial authority are not the best framework in which it feels very comfortable, which, although it has tacitly accepted the restrictions in the domain of violation of fundamental rights, cannot accept encroachment into the legal issues under its jurisdiction, nor by the Constitutional Court, and especially not from the side of other institutions. It seems that all three institutions must show a sufficient degree of will to establish mutual cooperation, as well as a sufficient degree of awareness of the impact of their decisions on the stability of a legal system.

\section{References}

Arlović, M., „Međuodnos Ustavnog suda Republike Hrvatske i sudbene vlasti u Republici Hrvatskoj”, Zbornik radova Pravnog fakulteta u Splitu 2/2015.

Bodiroga, N., „Ponavljanje parničnog postupka zbog odluke Ustavnog suda”, Anali Pravnog fakulteta u Beogradu 2/2013.

Vučić, O., Stojanović M. Dragan, „Evropski model ustavnog pravosuđa”, Zbornik radova Pravnog fakulteta u Nišu 69/2015.

Nastić, M., „Odnos Ustavnog suda i redovnih sudova - komentar odluke Ustavnog suda Republike Srbije", Zbornik radova Pravnog fakulteta u Nǐ̌u 65/2013.

Omejec, J., „Jurisprudencija nemačkog Saveznog ustavnog suda i hrvatsko ustavno sudstvo", u: Izbor odluka Ustavnog suda Savezne republike Nemačke (ur. Tobias Zern, Martin Bauch), Zaklada Konrad Adenauer program, Zagreb 2015.

Stojanović, D., „Ustavnosudsko ispitivanje sudskih odluka”, Zbornik radova Pravnog fakulteta u Nišu 74/2016.

\section{Website references}

Petrov, V., O promeni ustava i ustavnom sudu, intervju, Paragraf https:// www.paragraf.rs/intervju/vladan_petrov.html, 15. decembar 2018.

Rodin, S., „Odnos Ustavnog suda Republike Hrvatske i Suda pravde Europskih zajednica u Luksemburgu nakon ulaska Republike Hr- 
vatske u punopravno članstvo Europske unije", https://www. google.com/url? sa $=t \& r c t=j \& q=\&$ esrc $=s \&$ source $=w e b \& c$ $d=5 \& v e d=2$ ahUKEwjROrXO65LgAhXos 4 sKHcOiC7cQFjAEegQIBRAC\&url=https $\% 3 A \% 2 F \% 2 F b i b . i r b . h r \% 2 F$ datoteka\%2F388258. tekst_Rodin_out_final.doc\&usg=AOvVaw27rTpKT_4do5YVfV3Gdtdf.

\section{Srđan Jončić}

Sudija Prvog osnovnog suda u Beogradu

\section{KONFLIKT AUTORITETA SUDSKE VLASTI I NESUDSKIH INSTITUCIJA}

\section{Rezime}

Odnos sudske vlasti i nesudskih institucija koje donose odluke opšteobavezujućeg karaktera (ne mogu se preispitivatiu sudskom postupku), i kojima se zadire u nadležnost sudova, označavamo konfliktom autoriteta. Za razliku od odnosa sa institucijama koje nemaju ovlašćenja da utiču na vršenje sudske vlasti, i čije se delovanje može označiti kao "incidentno", konfliktni odnos sa Ustavnim sudom zasnovan je na postupanju suda, koji podrazumeva izlazak iz okvira legitimne zaštite "specifičnog ustavnog prava". Ovaj negativan aspekt delovanja Ustavnog suda, moguće je znatno ublažiti, ili možda potpuno eliminisati uvođenjem mehanizama samoograničenja i samokontrole u postupanju. Uspostavljanjem (samo) kontrolnih mehanizama, formirala bi se jasna predstava o karakteru i ozbiljnosti povrede osnovnih prava, odredila jasnija razlika između specifičnog ustavnog prava i običnog prava, i učvrstio stav o shvatanju zaštite osnovnih prava kao pitanje suštine, a ne forme.

Međutim, bez obzira na moguće pozitivne efekte kontrolnih mehanizama, uslov svih uslova za prevazilaženje nastalog konflikta je uspostavljanje intenzivne saradnje između institucija, i jačanje svesti o neophodnosti zajedničkog delovanja u oblasti zaštite temeljnih vrednosti našeg društva.

Ključne reči: Ustavni sud, sudska vlast, Državna revizorska institucija, konflikt, osnovna prava, autoritet institucija. 